\title{
Social emotions are governed by a common grammar of social valuation: Theoretical foundations and applications to human personality and the criminal justice system
}

\author{
Coltan Scrivner ${ }^{1,2}$, Daniel Sznycer ${ }^{3,4}$, Aaron W. Lukaszewski ${ }^{5}$, Laith Al-Shawaf ${ }^{6}$
}

\author{
${ }^{1}$ Department of Comparative Human Development, The University of Chicago \\ ${ }^{2}$ Institute for Mind and Biology, The University of Chicago \\ ${ }^{3}$ Department of Psychology, Oklahoma State University \\ ${ }^{4}$ Oklahoma Center for Evolutionary Analysis (OCEAN) \\ ${ }^{5}$ Department of Psychology, California State University, Fullerton \\ ${ }^{6}$ Department of Psychology, University of Colorado, Colorado Springs
}

\begin{abstract}
Social emotions appear to be behavior-regulating programs built by natural selection to solve adaptive problems in the domain of social valuation - the disposition to attend to, associate with, defer to, and aid target individuals based on their probable contributions to the fitness of the valuer. For example, shame functions to prevent and mitigate the costs of being socially devalued by others, whereas anger functions to correct those people who attach insufficient weight to the welfare of the self. Here we review theory and evidence suggesting that social emotions such as guilt, gratitude, anger, pride, shame, sadness, and envy are all governed by a common grammar of social valuation even when each emotion has its own distinct adaptive function and structure. We also provide evidence that social emotions and social valuation operate with a substantial degree of universality across cultures. This emotion-valuation constellation appears to shape human sociality through interpersonal interactions. Expanding upon this, we explore how signatures of this constellation may be evident in two spheres of human sociality: personality and the criminal justice system.
\end{abstract}

Keywords: Social emotions; social valuation; personality; criminal justice, emotion-valuation constellation 


\section{Social valuation and social emotions}

What underlies social valuation? Evolutionarily, the origin of valuation is closely linked with the degree to which a person positively or negatively impacts the fitness of the valuer. Numerous theories have been proposed to explain the evolution of psychological mechanisms that regulate conspecific valuation, including kin selection (Hamilton, 1964), reciprocation (Trivers, 1971), partner choice (Noë \& Hammerstein, 1994), reputation (Nowak \& Sigmund, 1998), risk-pooling (Kaplan \& Hill, 1985), and externality management (Tooby \& Cosmides, 1996). Stemming from these theories are a suite of empirical discoveries that mapped the neurocognitive architecture involved in computing the social value of a target to a valuer. The two key inputs processed by these neurocognitive mechanisms include (1) the target's probable contribution of fitness benefits to the valuer as, for example, kin, mate, trading partner, and fellow coalition member, and (2) the target's probable imposition of fitness costs on the valuer, if not appeased (Gilbert, 1997; Barclay \& Willer, 2007; Cacioppo et al., 1999; Cosmides, \& Tooby, 2019; Cuddy et al., 2008; Hare et al., 2010; Klein et al., 2008; Levy \& Glimcher, 2012; Lieberman et al., 2007; Lukaszewski et al., 2015; Sell et al., 2009; Sznycer et al., 2019; Sznycer, De Smet, et al., 2016). The direction and magnitude of these two classes of inputs jointly determine the social value of the target, which influences the degree to which the valuer will sacrifice his or her welfare for a target (Tooby et al., 2008).

Adaptive problems of social valuation include $(i)$ the value of self to others, $(i i)$ the value of others to the self; and (iii) the loss of valuable others. These adaptive problems would have led to the evolution of neurocognitive programs that efficiently and effectively compute variables relevant to social valuation and lead to on-average adaptive behavioral responses in the situations described above.

Emotions appear to play a central role in how humans solve adaptive problems of social valuation. Emotions have been characterized by evolutionary theorists as neurocognitive adaptations designed by natural selection to orchestrate cognition and behavior in the service of solving complex adaptive problems. The social emotions can be understood as a subset of emotions that solve problems of sociality (Tooby, 1985; Tooby \& Cosmides, 1990; Nesse, 1990; Ekman, 1992; Keltner \& Haidt, 1999; Darwin, 1872). These emotions function in part to recalibrate internal variables of the cognitive architecture, including variables that index the social valuations assigned by self and others (Tooby \& Cosmides, 2008; Sell et al., 2009; Sznycer, Cosmides, et al., 2017; Sznycer, Lopez Seal, et al., 2017; Delton \& Robertson, 2016; Al-Shawaf et al., 2016; Al-Shawaf \& Lewis, 2017; Sznycer et al., forthcoming). With its emphasis on adaptive problem and adaptive function, this perspective can make sense of many known facts about the social emotions, because natural selection produces close fits between the structure of an adaptive problem and the features of the adaptation that evolved to solve it. For example:

- Gratitude appears designed to enhance cooperation with a social partner (Algoe et al., 2008; Lim, 2012; Smith et al., 2017). Gratitude is triggered by indications that a conspecific values the focal individual more than expected (Algoe et al., 2008; Lim, 2012; Smith et al., 2017; Tesser, Gatewood, \& Driver, 1968; Tsang, 2006a, 2006b). Once activated, gratitude increases the value the individual attaches to the conspecific's welfare (Gordon et al., 2012; Lim, 2012; Smith et al., 2017), which can lead to an escalating 
cycle of mutual valuation, along with beneficial outcomes for both parties (Algoe et al., 2013; Algoe et al., 2008; Tooby \& Cosmides, 1996).

- Pride appears to motivate the achievement and advertisement of socially valued acts or traits by someone so that others place more value on that individual's welfare (Fessler, 1999; Weisfeld, 1999; Tracy, Shariff, \& Cheng, 2010; Sznycer, Al-Shawaf, et al., 2017; Cohen et al., 2020; Sznycer \& Cohen, forthcoming-a; Schniter et al., 2020; Durkee et al., 2019). Pride is triggered in response to achievements - events indicating that an individual has an enhanced capacity to deliver benefits or impose costs on others, along with an associated increase in status (Lewis et al., 1992; Tracy \& Matsumoto, 2008). When triggered, the pride system advertises achievements, motivates continued investment in courses of action that bring about achievement, and solicits enhanced valuation from others (Cheng et al., 2013; Riskind \& Gotay, 1982; Tracy \& Robins, 2008; Weisfeld, 1999; Williams \& DeSteno, 2008; ).

Anger functions to bargain for better treatment (Sell, 2011; Sell et al., 2017; Sell \& Sznycer, this volume). Anger is activated in response to indications that another person places insufficient value on the welfare of the focal individual-less value than the individual feels entitled to (Sell et al., 2009, 2017). Once triggered, the anger system deploys various tactics to incentivize the other to increase her valuation of the individual: communication of the anger state (Galati et al., 2003; Sell et al., 2014), arguments (Averill, 1982; Sell et al., 2017), and threats of (or actual) withdrawal of assistance or imposition of costs (Daly \& Wilson, 1988; Felson, 1982; Sell, 2011).

- Guilt appears designed to remedy situations where one put insufficient weight on the welfare of a valuable other (often unintentionally), independent of whether the other person knows this (Baumeister et al., 1994; Leith \& Baumeister, 1998; Smith et al., 2002; McGraw, 1987; Tooby \& Cosmides, 2008; Sznycer, 2010, 2019). Once triggered, the guilt system increases the value the focal individual attaches to the other's welfare: It interrupts the imposition of costs (Cohen et al., 2013; Cohen et al., 2014) and motivates actions to benefit the victim and repair the relationship through restitutions, amends, apologies, confessions, and acceptance of responsibility (Baumeister et al., 1995; Tangney, 1991; de Hooge et al., 2007; Ketelaar \& Au, 2003; Leith \& Baumeister, 1998; Ohtsubo \& Yagi, 2015; Sznycer et al., 2015; Schniter et al., 2013).

- Sadness is activated by the separation, incapacitation, or death of associates who may otherwise value the individual's welfare and make positive fitness contributions to her (Tooby \& Cosmides, 1990; Keller \& Nesse, 2006; see also Hagen, 1999; Hagen \& Barrett, 2007). When activated, sadness reduces the motivation to move and to act (Michalak et al., 2009), a response that can prevent behaviors causing further loss (Keller $\&$ Nesse, 2006; Welling, 2003). Also, sadness may prompt cognitive activity geared to solve problems related to the loss or to adapt to the loss (Andrews \& Thomson, 2009).

- Shame functions to minimize the spread of negative information about the self and the cost of any ensuing devaluation from others (Gilbert, 1997; Fessler, 1999; Weisfeld \& Dillon, 2012; Sznycer, Tooby, et al., 2016; Sznycer \& Cohen, forthcoming-b; Durkee et 
al., 2019; Landers et al., this volume). Shame is triggered by indications of probable or actual social devaluation (Smith, Webster, \& Eyre, 2002; Dickerson et al., 2008;

Robertson et al., 2018). Shame motivates the individual to inhibit actions that may cause further social devaluation (de Hooge et al., 2008; Fehr \& Gächter, 2000), to conceal incriminating information (Leach \& Cidam, 2015; Sznycer et al., 2015), and to withdraw from the situation (Wicker et al., 1983). When ashamed, the individual appeases (Keltner et al., 1997) and produces a stereotyped nonverbal display that deters attacks by signaling subordination (Keltner et al., 1997; Fessler, 1999; Gilbert, 2000; Tracy \& Matsumoto, 2008; Weisfeld \& Dillon, 2012).

- Envy is elicited by indications of competitive superiority in one's positional rivals. Envy functions to suppress the advantages of one's rivals, a strategy which may be beneficial for the focal individual in zero-sum competitions (Foster, 1965; Hill \& Buss, 2008; Schoeck, 1969; Smith \& Kim, 2007; Gershman, 2015; Sznycer, Lopez Seal, et al., 2017; Lin \& Bates, 2020). Envy even motivates the imposition of costs on rivals when the actions are costly to the envious individual himself. Envy combines spite and stealth in the deployment of the spite (Schoeck, 1969). The stealth appears to be a design feature to minimize the cost of spite to the envious individual. Without stealth, the focal individual may face serious costs: spite invites its targets to retaliate against the spiteful individual, the targets of envious spite tend to be (by definition) in a superior position to retaliate, and envy can be understood as an implicit admission of competitive disadvantage that can be used to exploit the envious individual. Envy is associated with schadenfreude - joy in the misfortune of others (Brigham et al., 1997; van Dijk et al., 2015; Sznycer et al., in prep.).

Each of these social emotions - gratitude, pride, anger, guilt, sadness, shame, and envy are triggered by specific inputs and produce cognitive and behavioral outputs that appear to be functional in solving specific adaptive problems; they have particular information-processing procedures, core-affective properties (Nelson \& Russell, 2014; Russell, 1980), physiological signatures (Blascovich \& Mendes, 2010; Siegel et al., 2018), and behavioral repertoires.

Here, we argue that despite the functional and structural differences between the different social emotions, they may all be informed by a common set of evaluations. The human mind is expected to aptly appraise the events that trigger these emotions in the local ecology. That is, the mind is expected to accurately estimate the social value that is imputed locally to, for example, being generous, which may form the basis of the activation of pride (if one is generous), the activation of envy (if a rival is generous), and so on. Indeed, it has been hypothesized that the human mind features a generative grammar with universal principles and open parameters that computes the social value of an individual based on that individual's actions (e.g., shares food), traits (e.g., physically formidable), and characteristics (e.g., sibling of chief), and that social emotions consult relevant social values to modulate their operation (Jackendoff, 2006; Tooby \& Cosmides, 2008; Sznycer, Al-Shawaf, et al., 2017; Sznycer, 2019). 


\section{The grammar of valuation}

A prediction can be derived from this line of reasoning about social valuation: If performing an action or displaying a trait leads to a positive or negative evaluation of a target individual, then that action or trait may elicit multiple social emotions. For example, wisdom might be a trait that is valued by members of a social group (that is, a positive valuation is attached to those who display wisdom). In this group, pride may be activated in a person who displays wisdom, they may feel anger if their wisdom is not recognized, the death of a wise person may trigger sadness, a person may feel shame if they publicly do something that is unwise, guilt may be triggered in a person who unintentionally undervalues a wise person, and envy may be triggered if one's rival displays wisdom. In each case, the trait (wisdom) is being consulted by the social emotion (pride, anger, sadness, shame, guilt, envy) when the input condition of the emotion is met - having the valued trait in the case of pride, not receiving enough respect for possessing the trait in the case of anger, losing a close other who has the trait in the case of sadness, inadvertently under-valuing someone who possesses the trait in the case of guilt, and others believing that you lack the trait in the case of shame.

A key part of the conceptual framework of the grammar of valuation is that the local value attached to the action or trait (wisdom, in this example) will be - as a first approximation the same, regardless of which social emotion is accessing the value. For example, the value placed on wisdom in some local ecology would be the same whether it is being accessed by the pride system or the anger system. From this, it may be predicted that the degree to which a trait/action is valued will correspond with the intensity of the social emotion that is triggered by the trait/action. In other words, the more an act causes community members to socially value a target individual who performed that act, the more intense emotions will be mobilized in response to a situation involving that act. Critically, this should be true not only for a single emotion triggered by the action/trait, but also across multiple social emotions that are triggered by the corresponding input situation that involves that action/trait. For example, if athleticism is more highly valued than botanical knowledge in a given social ecology, then, everything else being equal, the intensity of anger will be higher when, e.g., someone fails to acknowledge one's athleticism than when someone fails to acknowledge one's botanical knowledge; the intensity of gratitude will be higher when someone convinces others that one is athletic than when someone convinces others that one has botanical knowledge; the intensity of envy will be higher when one's rival has superior athleticism compared to when one's rival displays superior botanical knowledge, and so on.

Matching the intensity of emotion to the precise value of the elicitor is necessary, because over-activation and under-activation of an emotion relative to the eliciting condition are costly errors. If social emotions are well-engineered adaptations, they should make valuation estimates based on the local social ecology. In some cases, an inaccurate estimate may lead to an emotional display that is not cost-efficient. For example, displaying too much shame for a minor offense means that one accepts steeper devaluation from others than what is warranted by the facts - a maladaptive response. Similarly, displaying too little shame can also result in shunning and the imposition of costs. In some cases, an inaccurate estimate may actually lead to devaluation, such as exhibiting too much pride when it is unwarranted. To guide emotion-activation in a functional manner, social emotions should consult the grammar of valuation to estimate the value that the relevant action or trait affords to local audiences and modulate their activation accordingly. 
One of the key functions of emotions is to evaluate future courses of action (Bechara et al., 2000; Schwarz, 2000; Sznycer, Tooby, et al., 2016). However, the ability to evaluate future courses of action only when audience feedback is available would be inefficient, particularly in a species that is equipped with imagination and prospection. Because of this, social emotions should track action/trait valuations even in the absence of communication between the audience and the focal individual. In other words, social emotions are expected to mobilize in anticipation and during the imagining of their respective input situation, and not just during the actual situation (Van Der Schalk et al., 2012). From this, we can predict that the anticipated or imagined intensity of social emotions will accurately and precisely track the values afforded to audiences by the relevant acts and traits.

\section{The grammar of valuation appears to be universal}

The argument so far makes the case that the information-processing structure of social emotions and the grammar of valuation are evolved, species-typical adaptations in humans. If this is the case, the predicted associations between social valuation and the intensities of multiple emotions should be observable within populations worldwide and, in some cases, even between populations. Given the variety of human social ecologies, some actions, traits, and situations bring about evaluative responses and emotions in certain populations but not in others (Haidt, 2012; von Fürer-Haimendorf, 1967; Sznycer, Tooby, et al., 2016). Still, if some universal principles exist within the grammar of valuation, then actions, traits, and situations that tap into these principles may elicit agreement between populations about social valuation and emotions. Moreover, multiple emotions in one population may track the valuations that people hold in a different population.

Previous studies on the emotion of pride have supported these predictions. Studies conducted in 16 industrial countries indicate that the degree to which pride is anticipated following a particular action or trait closely tracks the degree to which audiences value the individual who performs that action or displays that trait (Sznycer, Al-Shawaf, et al., 2017; see also Durkee et al., 2019; Cohen et al., 2020; Leary et al., 1995). Moreover, the anticipated pride in each of the 16 countries tracked the valuations expressed by foreign audiences in the other 15 countries. For example, the more South Korean participants valued a target individual for having a certain trait, the more Swiss participants reported pride if they displayed that trait. Furthermore, these findings replicated in 10 traditional small-scale societies (Sznycer, Xygalatas, Alami, et al., 2018). Importantly, it was pride that tracked valuation; other positively-valenced emotions did not uniquely track audience valuations (Sznycer, Al-Shawaf, et al., 2017), pointing to the functional specificity of pride.

Similar findings apply to shame. As noted above, the shame system functions to minimize the threat of being devalued by others when negative information about the self might be revealed (or has been revealed) to others. If the shame program is well-calibrated to the evaluations of audiences, one may expect people to feel intense shame regarding personal actions or traits that audiences disvalue greatly, and less intense shame regarding personal actions or traits that audiences devalue mildly. Indeed, studies in industrial societies and traditional smallscale societies show that shame accurately tracks the degree of devaluation expressed by both local audiences and foreign audiences (Sznycer, Tooby, et al., 2016; Sznycer, Xygalatas, Agey, et al., 2018; Durkee et al., 2019; Cohen et al., 2020). These findings are consistent with the 
hypotheses that the psychology of social valuation and the emotions of pride and shame are evolved, species-wide adaptations.

More recently, Sznycer and Lukaszewski (2019) have reported similar findings regarding other social emotions. Participants from the United States and India rated 25 hypothetical scenarios developed by Sznycer, Al-Shawaf, et al. (2017) in which someone's actions, traits, or circumstances might lead them to be viewed positively by others. The scenarios were designed to elicit reactions in a wide variety of evolutionarily relevant domains, such as social exchange, skills, aggressive contests, mating, parenting, and leadership, and were phrased at a relatively high level of abstraction to make them meaningful across different cultures.
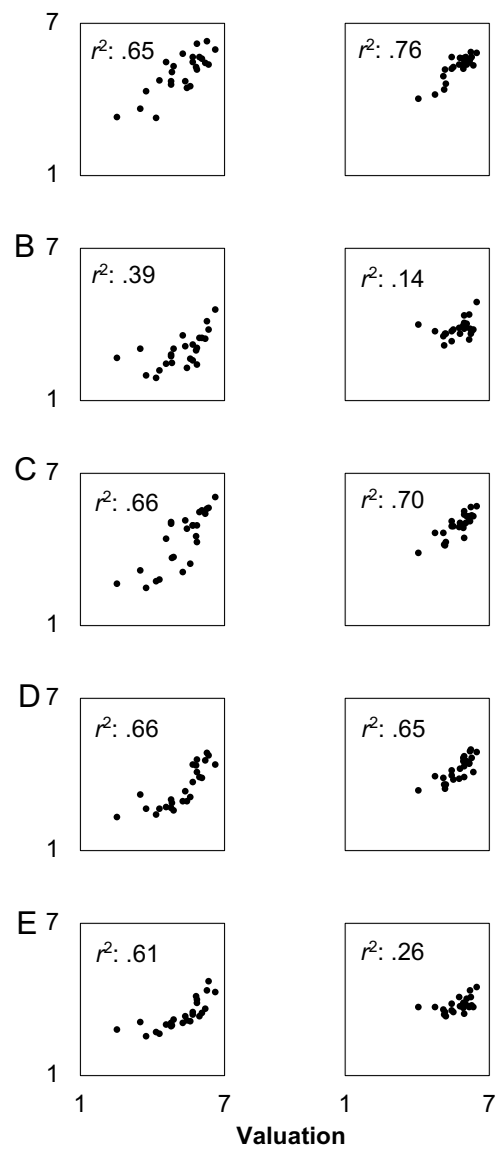

Figure 1. Multiple social emotions track social valuation. The extent to which people value each of 25 positive personal characteristics in others (e.g., trustworthiness, bravery, ambitiousness, good table manners) is positively associated with the intensities of: pride (if you had those characteristics), anger (if someone failed to acknowledge that you have those characteristics), gratitude (if someone convinced others that you have those characteristics), sadness (if someone died who had those characteristics), and guilt (if you harmed someone who has those characteristics). Each point in each panel represents the mean valuation rating and mean emotion rating of one personal characteristic. Ratings of valuation, pride, anger, gratitude, sadness, and guilt were given by different participants (between-subjects design). $\mathrm{N}$ on which the correlations are based $=$ number of personal characteristics $=$ 25. Effect size: $r^{2}$ linear. United States data: panels A-E; India data: panels F-J. Reprinted with permission from: Sznycer, D. \& Lukaszewski, A. W. (2019). The emotion-valuation constellation: Multiple emotions are governed by a common grammar of social valuation. Evolution and Human Behavior, 40(4), 395-404. 
Participants were randomly assigned to one of six conditions: valuation, guilt, sadness, pride, anger, and gratitude. Participants in each condition rated the same basic set of 25 scenarios. What varied across conditions was a prompt, displayed before the scenarios. The prompts were designed to guide the interpretation of the scenarios in a way that would elicit valuation of a target individual or one of five emotions (guilt, sadness, pride, anger, or gratitude). For example, in the valuation condition, the prompt asked participants to imagine that the actions and traits described in the 25 scenarios are true of a target individual: an individual other than the participant who is of the same sex and age as the participant. Participants then rated how they viewed the person from 1 (I wouldn't view them positively at all) to 7 (I'd view them very positively). The five emotion conditions had similar prompts with situation-specific scenarios meant to elicit the respective emotion and a 1-7 rating for the emotion. For example, in the pride condition, the prompt asked participants to imagine that the acts and traits described in the 25 scenarios are true of themselves, and to indicate how much pride they would feel if they were in those situations ( 1 - no pride at all; 7 - a lot of pride).

In sum, participants rated, for each of 25 scenarios describing positive acts and traits, either: (i) valuation of another individual, if those things were true of that individual; (ii) guilt, if those things were true of another individual on whom the participant has imposed costs - in the absence of any incriminating evidence that publicly reveal this imposition of costs; (iii) sadness, if those things were true of a recently deceased neighbor; ( $i v)$ pride, if those things were true of themselves; ( $v$ ) anger, if a friend failed to acknowledge those things about them; or ( $v i$ ) gratitude, if a friend convinced others that those things are true of the participant.

Sznycer \& Lukaszewski (2019) found that the degree to which local audiences positively value a target individual if various acts or traits are true of the target is positively associated with the degree to which people feel each of the five different social emotions (Figure 1). Not only did the results hold in both the US and India, but audience valuations in each country were associated with the intensities of the five emotions in the other country (Figure 2). This serves as the first empirical evidence that multiple social emotions with highly different functions, computational properties, and phenomenologies are governed in part by a common grammar of social valuation.

In addition to within- and between-culture regularities in emotion, this theoretical framework may also help explain cultural differences in emotion (Sznycer et al., 2012; Sznycer, Tooby, et al., 2016, Study S2; Sznycer, Al-Shawaf, et al., 2017, Study S1; see also Mesquita \& Frijda, 1992; Scherer \& Wallbott, 1994; Elfenbein \& Ambady, 2002; Al-Shawaf \& Lewis, 2017). The more an action or trait is valued in culture $A$ compared to culture $B$, the more that action or trait is expected to elicit various social emotions in culture $A$ compared to culture $B$. Sznycer \& Lukaszewski (2019) found evidence for this prediction as well. This approach can therefore account for - and more importantly, predict in advance - cross-cultural regularities and cross-cultural differences in social emotions.

In sum, the human mind-brain appears to be equipped with a complex psychology of social valuation and a suite of emotions that recalibrate internal representations of social value in the minds of self and others. This emotion-valuation constellation shapes the form of interpersonal interactions: with whom we associate, to whom we attend, whom we help, to whom we are grateful, whom we spite, and so on. If the emotion-valuation constellation is a pillar of human sociality, then signatures of this constellation may be evident in various spheres of human behavior and sociality. Next, we briefly review evidence in two such spheres-personality and the criminal justice system - suggesting that this is indeed the case. 

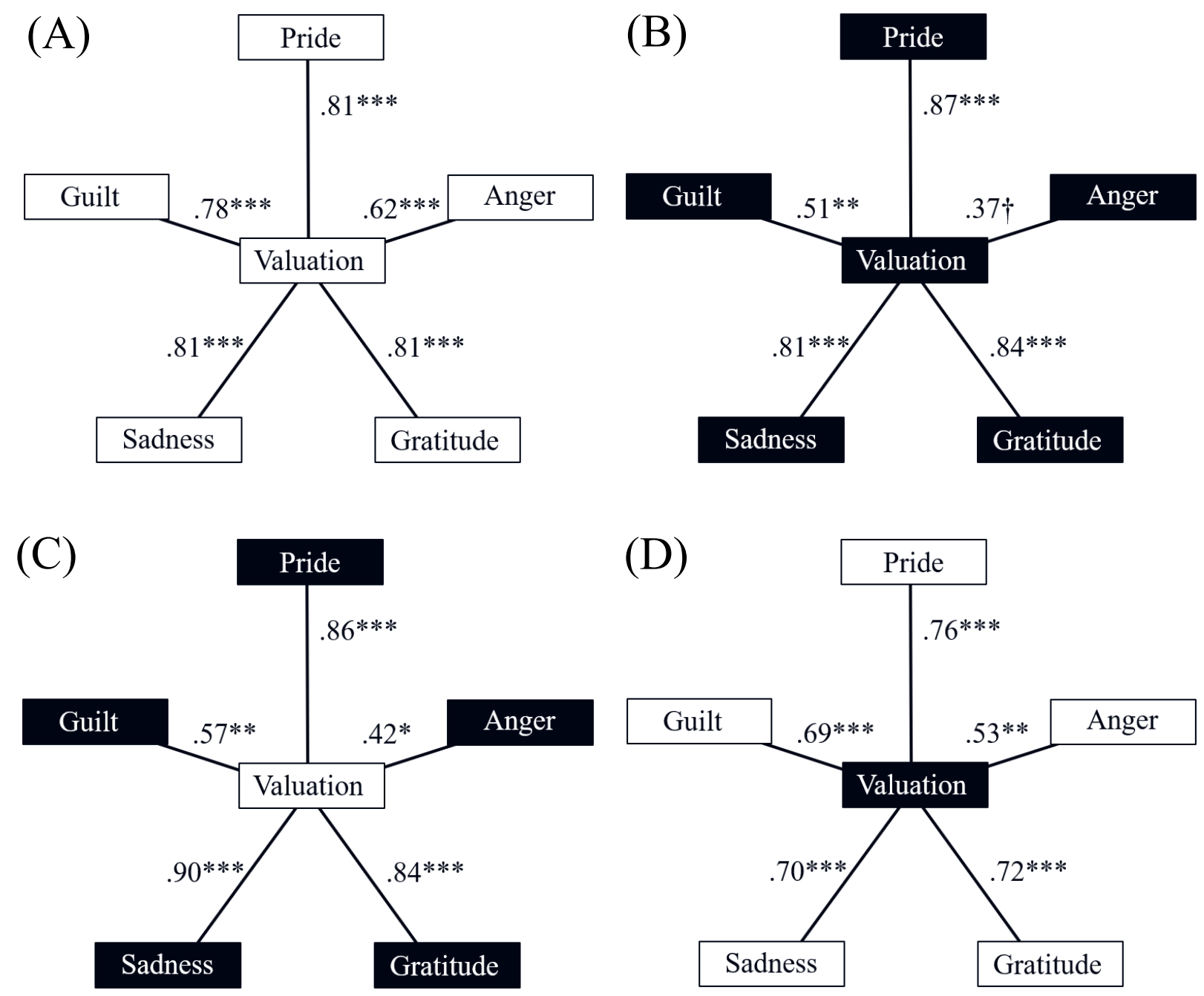

Figure 2. Multiple social emotions track social valuation both within- and between-countries. The valuations expressed by American participants are positively associated with the intensities of pride, anger, gratitude, sadness, and guilt expressed by American participants (panel A) and by Indian participants (panel C). Similarly, the valuations expressed by Indian participants are positively associated with the intensities of pride, anger, gratitude, sadness, and guilt expressed by Indian participants (panel B) and by American participants (panel D). N on which the correlations are based $=$ number of personal characteristics $=25$. Ratings of valuation, pride, anger, gratitude, sadness, and guilt were given by different participants (between-subjects design). Numbers represent Pearson's $r$ between valuation and each emotion. $* * * p<.001 ; * * p<.01 ; * p<.05 ; \dagger .05<p<.10$. Reprinted with permission from: Sznycer, D. \& Lukaszewski, A. W. (2019). The emotion-valuation constellation: Multiple emotions are governed by a common grammar of social valuation. Evolution and Human Behavior, 40(4), 395-404. 


\section{Signatures of the emotion-valuation constellation I: Personality}

The hypothesis that emotions underlie individual differences in personality - characteristic ways of thinking and behaving — has a long history in psychology (e.g., Allport \& Allport, 1921; Mischel \& Shoda, 1995; Montag \& Panksepp, 2017). This hypothesis is compatible with a recently developed adaptationist framework for discovering the psychological underpinnings of descriptive personality constructs, such as the Big Five (Saucier \& Goldberg, 1996) and Big Six (Ashton \& Lee, 2007) dimensions (Lukaszewski, 2020; Lukaszewski et al., 2020). This framework holds that, if we are to identify and characterize the psychological mechanisms that generate behavioral variation captured descriptively in nebulous personality dimensions (e.g., "Conscientiousness"), it is essential to begin by building theory-based models of specific behavior-regulating mechanisms. From this perspective, emotions are good candidates to explain personality variation, owing in part to their role in orchestrating functional responses to adaptive problems across many neurocognitive systems (Al-Shawaf et al., 2016; Al-Shawaf \& Lewis, 2017; Tooby \& Cosmides, 1990). For example, variation in the fear system — whether at the level of individual differences or within people across situations - will orchestrate variation in physiology (e.g., heart rate), attention (e.g., a bias toward detecting threats), and manifest behavior (e.g., fearful facial expression). Once the architecture of fear is provisionally mapped via an adaptationist analysis, the scientist can begin to determine whether variation in fear's activation and outputs are described in the folk parlance of any extant personality constructs (e.g., aspects of Big Five "Neuroticism"; Davis \& Panksepp, 2011).

If variation in emotions constitutes (part of) the mechanistic underpinnings of personality, then it is possible that many personality constructs may describe variable behavioral solutions to adaptive problems pertaining to social valuation. For example, as detailed above, anger exhibits strong evidence of special design for solving the adaptive problem of being insufficiently valued by others (Sell et al., 2009; 2017; Tooby et al., 2008). Recently, researchers discovered that both within- and between-person variation in anger's activation and outputs are described in the folklexical parlance of the HEXACO (i.e., Big Six) personality dimension labeled "Agreeableness" (Lukaszewski et al., 2020). These findings illustrate (1) the utility of an adaptationist framework for characterizing the mechanisms that give rise to functionally defined dimensions of variation, and (2) the potential superiority of personality taxonomies that are organized around theoretically based dimensions of variation, rather than the largely atheoretical factor-analytical decisions that have historically characterized personality psychology.

A personality taxonomy grounded in the emotion-valuation constellation would capture dimensions of variation that carve the mind at its natural joints, while elucidating the psychological foundations of extant personality dimensions. Much as anger appears to form the mechanistic underpinning of Agreeableness, evidence suggests that variation in the pride (Cheng et al., 2010), shame (Gramzow \& Tangey, 1992), envy (Krizan \& Johar, 2012), and contempt (Gervais \& Fessler, 2013) programs are descriptively captured in aspects of the "Dark Triad" personality dimensions of Narcissism, Machiavellianism, and Psychopathy (Jones \& Paulhus, 2014). Further developing theory-based models of within- and between-person variation in the social emotions - as well as the psychometric tools for assessing such variation - may reveal that much of human "personality" is organized around a constellation of adaptive problems pertaining to social valuation. We envision a social-personality science in which researchers don't study lexically-based trait factors such as "Conscientiousness" and "Agreeableness," but 
rather the universal and variable design features of adaptations such as anger, envy, gratitude, pride, shame, and sadness.

The cognitive grammar of social valuation referenced by social emotions to calibrate their operation is likely an important source of both universals in emotions and individual differences. This is true in multiple ways. First, if multiple social emotions consult a common grammar of valuation, then individual differences in how people represent the social value attached to specific acts and traits will lead to individual differences in how those acts or traits trigger emotions. For example, if person A represents eloquence as being more locally valued than person B, then instances of linguistic virtuosity (or incoherence) will correspondingly activate multiple social emotions more intensely in A than B (e.g., pride in response to successfully regaling others; shame in response to public inarticulateness; envy in response to a rival's celebrated speech at the community meeting; etc.). As such, the "common grammar" framework provides the foundation for understanding both universality and individual differences in emotions. It will be crucial for future work in this area to consider not only the substantial uniformity between people in how the emotion-valuation constellation works, but also the systematically predictable differences between cultures and individuals therein.

Variation in the grammar of social valuation is likely key in the decision process by which the activation of a given social emotion leads to specific behavioral outputs. Given the massive set of possible 'on-the-ground' contingencies involved in solving a given adaptive problem in a specific circumstance, an emotion program requires access to a decision architecture that can precisely tailor behavioral decisions to the current situational and cultural context (Buss, 1991; Lukaszewski et al., 2020). For example, shame, when activated by potential or actual devaluation, must be able to improvise, or select from among, potentially functional behavioral outputs - should I hide, play dumb, make aggressive threats, cut off one of my fingers, or something else? Buss (1991) proposed a hierarchical structure of tactical output selection wherein specific behavioral outputs are nested within broader act categories. Given that the entire space of specific behavioral outputs that could be deployed in a given situation is nearly infinite-ranging from [rub your tummy] to [make a sexual proposition] to [brandish a weapon] - a decision architecture attempting to select outputs from this space would become paralyzed in the face of combinatorial explosion (Tooby \& Cosmides, 1992). Rather, shame, when activated, will circumscribe the decision space to the level of broad act categories (e.g., [prevent others from knowing about disvalued act] vs. [generate compensatory benefits for others] that would have solved the adaptive problem ancestrally, or within one's own ecology. Next, having selected a broad act category (e.g., [prevent others from knowing about disvalued act]), shame must be able to tailor plausibly functional behavioral outputs (e.g., [falsely blame someone else] or [slip away inconspicuously before they see me] to the details of the current situation, taking into account the devaluers' identities and various situational and cultural variables. In this process, within- or between-culture variation in peoples' representation of the extent to which specific acts (or broad act categories) are (dis)valued will play a crucial role in determining which behavioral decisions have the greatest forecasted payoff in the currency of mitigating the costs of social devaluation. For instance, if person A represents being caught in a lie as being more strongly disvalued than person B, then person A will be less likely than B to select the behavioral output [falsely blame someone else]. The same would hold for specific behavioral decisions motivated by any of the social emotions comprising the emotion-valuation constellation. 
In sum, the structure of the emotion-valuation constellation, as well as that of its constituent components, may influence a wide range of psychological and behavioral phenomena that have traditionally been studied as aspects of "personality." Mapping the variable parameters of the grammar of social valuation, as well as the social emotions, may therefore help place personality psychology on a new footing - one that carves the mind at its joints, and supplies a framework within which to seamlessly explain within-person, between-person, and cross-cultural variation in behavior.

\section{Signatures of the emotion-valuation constellation II: The criminal justice system}

Modern skulls house stone-aged minds - the agricultural and industrial revolutions occurred too recently for natural selection to have effected major reorganizations of the human neurocognitive architecture (Tooby \& Cosmides, 1992). One consequence of this is that modern artifacts and institutions are underlain by ancient adaptations for life in prehistoric small-scale bands of foragers, and signatures of the latter can be seen in the design of the former (Tooby \& Cosmides, 1992; Boyer, 2018).

This general hypothesis has been applied to study war (Tooby \& Cosmides, 1988; Manson et al., 1991; Sell, Tooby, \& Cosmides, 2009; Sell et al., 2017; Brown et al., 2021), religion (Boyer, 2008; Barlev et al., 2017; Lang et al., 2019), rituals (Boyer \& Liénard, 2006; Xygalatas et al., 2013), politics (Pietraszewski et al., 2015), morality (Alexander, 1987; Curry et al., 2019; DeScioli \& Kurzban, 2013; Lieberman \& Patrick, 2018; Tooby \& Cosmides, 2010), criminal laws (Jones, 2001; Jones \& Goldsmith, 2005; Robinson et al., 2007; Stylianou, 2003; Sznycer \& Patrick, 2020), redistribution (Petersen et al., 2012, 2013; Sznycer, Lopez Seal, et al., 2017; Sznycer, Ermer, et al., 2018; Lin \& Bates, 2020), the family (Daly \& Wilson, 1995; Lieberman et al., 2007; Salmon \& Shackelford, 2007; Sznycer, De Smet, et al., 2016), markets (Boyer \& Petersen, 2018; Friedman, 2005; Rubin, 2003), and property rights (Friedman, 2010; Kanngiesser et al., 2020) among other areas of study.

The emotion-valuation constellation regulates how individuals allocate goods and bads (attention, aid, exclusion, exploitation) between themselves and others depending on the characteristics or externalities or contributions of self and others. If societal institutions are created and interpreted (at least in part) through the lens of adaptations for interpersonal interactions (Tooby et al., 2006; Sznycer, Lopez Seal, et al., 2017; Boyer, 2018), then the emotion-valuation constellation may shape (at least in part) the institutions that regulate the allocation of goods and bads among people in a society. If so, then signatures of the emotionvaluation constellation will be discernible in those institutions.

Put simply, the rules that regulate some institutions may be traceable to evaluative and emotional-recalibrational processes that evolved as solutions to problems in the domain of interpersonal interactions. Just as individuals condition their help to those individuals who help back, so institutions may condition rewards to those individuals who contribute to the public good or the collective action. Just as individuals devalue and exclude those individuals who are exploitative, so institutions may devalue and punish those individuals who exploit a common resource. And so on. Moreover, if there are commonalities across cultures in the circuit-logic of the emotion-valuation constellation, then (some) institutions in population A may be traceable to the social evaluations and the social emotions of individuals in population B-even when populations A and B exist in different times, geographical spaces, cultural spaces, and ecologies. 
As an example of this, consider the institution of the criminal justice system. Humans can create costs for others as a side-effect of their actions, and they can benefit at the expense of others in various ways. Given the recurring and consequential nature of conflict to human social life, natural selection would have selected for adaptations to navigate conflict (Cosmides \& Tooby, 2006; Jones \& Goldsmith, 2005; Patrick, 2016; Robinson et al., 2007; Sell et al., 2009; Sell, 2011). Some of these adaptations are in the purview of the emotion-valuation constellation: victims' devaluation of offenders, victims' anger directed at offenders, perpetrators' shame and guilt, and so on. Thus, criminal justice systems may bear the stamp of the emotion-valuation constellation.

Consistent with this hypothesis, research suggests that social evaluations and social emotions are important components of people's intuitions of justice as well as criminal laws (where formal criminal laws exist). For example, laypeople agree both within and across countries in how they rank the seriousness of different offences (Robinson \& Kurzban, 2007; Stylianou, 2003) Further, laypeople's justice intuitions generally track the punishments prescribed by the legal codes and judges of their jurisdiction (Kääriäinen, 2018; Robinson et al., 2010).

Recently, Sznycer \& Patrick (2020) have shown that laypeople's social evaluations and social emotions closely match the logic and content of laws drawn from ancient Mesopotamian and Chinese legal codes (the Laws of Eshnunna, 1770 BCE; the Tang Code, 635 CE). Study participants with no legal training from the United States and India were shown various ancient offenses as defined in ancient laws. The corresponding punishments provided for those offenses by the ancient laws were not shown to participants. Participants were asked to rate each offense. Participants' responses were positively correlated with the actual punishments provided for those ancient offenses by the ancient laws. This was true for a host of responses, including interpersonal devaluation of offenders, judgements of moral wrongness, mock-legislated punishments (in time in prison and in fines), and perpetrator shame. In addition, the valuation psychology can be seen in the administration of justice, as the mode and intensity of recommended punishment for an offense is more severe when participants perceive offenders to have lower social value, and victims to have higher social value (Lieberman \& Linke, 2007; Petersen et al., 2012; see also Williams et al., 2019).

In sum, laypeople can intuitively recreate criminal laws from both familiar and radically unfamiliar cultures, and they can do this in the absence of explicit legal or historical knowledge. They appear to accomplish this through their social evaluations and emotions. This suggests that the emotion-valuation constellation may underlie key aspects of criminal justice systems. We suspect that signatures of the emotion-valuation constellation will be found in other institutions as well.

\section{Concluding remarks}

The emotion-valuation constellation governs whom we value and help, to whom we are indifferent, whom we disvalue and exclude, when we feel anger and demand to be treated better, when we hide in shame, and when we advertise our achievements.

This constellation seems to be a fulcrum of human sociality. Its importance in human affairs is difficult to overstate. For instance, the flow of goods, services, and capital - the economy-is determined to an important extent by who values whom and who values whose assets. The 
criminal justice system too may be shaped by social valuation, as argued above. Individual differences in personality may also be an outcrop of the emotion-valuation constellation.

Many basic questions remain to be answered about the structure of this common grammar and which aspects of human psychology it underlies. However, the specificity and replicability of the findings outlined here suggest that an evolutionary approach sheds new light on how emotions function and what aspects of behavior and psychology they underpin.

\section{References}

Algoe, S. B., Fredrickson, B. L., \& Gable, S. L. (2013). The social functions of the emotion of gratitude via expression. Emotion, 13(4), 605. https://psycnet.apa.org/doi/10.1037/a0032701

Algoe, S. B., Haidt, J., \& Gable, S. L. (2008). Beyond reciprocity: Gratitude and relationships in everyday life. Emotion, 8, 425-429. https://psycnet.apa.org/doi/10.1037/1528$\underline{3542.8 .3 .425}$

Al-Shawaf, L., Conroy-Beam, D., Asao, K., \& Buss, D. M. (2016). Human emotions: An evolutionary psychological perspective. Emotion Review, 8(2), 173-186. https://doi.org/10.1177\%2F1754073914565518

Al-Shawaf, L., \& Lewis, D.M.G. (2017). Evolutionary psychology and the emotions. In V. Zeigler-Hill and T.K. Shackelford (Eds.), Encyclopedia of Personality and Individual Differences. Springer.

Alexander, R. D. (1987). The biology of moral systems. Transaction Publishers.

Allport, F. H., \& Allport, G. W. (1921). Personality Traits: Their Classification and Measurement. The Journal of Abnormal Psychology and Social Psychology, 16(1), 6-40. https://psycnet.apa.org/doi/10.1037/h0069790

Andrews, P. W., \& Thomson, J. A., Jr. (2009). The bright side of being blue: Depression as an adaptation for analyzing complex problems. Psychological Review, 116(3), 620-654. https://doi.apa.org/doi/10.1037/a0016242

Ashton, M. C., \& Lee, K. (2007). Empirical, theoretical, and practical advantages of the HEXACO model of personality structure. Personality and social psychology review, 11(2), 150-166. https://doi.org/10.1177\%2F1088868306294907

Averill, J. R. (1982). Anger and aggression: An essay on emotion. Springer.

Barclay, P., \& Willer, R. (2007). Partner choice creates competitive altruism in humans. Proceedings of the Royal Society of London B: Biological Sciences, 274(1610), 749-753. https://doi.org/10.1098/rspb.2006.0209

Barlev, M., Mermelstein, S., \& German, T. C. (2017). Core intuitions about persons coexist and interfere with acquired Christian beliefs about God. Cognitive Science, 41, 425-454. https://doi.org/10.1111/cogs.12435

Baumeister, R. F., Stillwell, A. M., \& Heatherton, T. F. (1994). Guilt: An interpersonal approach. Psychological Bulletin, 115, 243-267. https://psycnet.apa.org/doi/10.1037/0033-2909.115.2.243

Baumeister, R. F., Stillwell, A. M., \& Heatherton, T. F. (1995). Personal narratives about guilt: Role in action control and interpersonal relationships. Basic and Applied Social Psychology, 17, 173-198. https://psycnet.apa.org/doi/10.1207/s15324834basp1701\&2 10

Bechara, A., Damasio, H., \& Damasio, A. R. (2000). Emotion, decision making and the 
orbitofrontal cortex. Cerebral Cortex, 10(3), 295-307.

https://doi.org/10.1016/j.pscychresns.2015.01.013

Blascovich, J., \& Mendes, W. B. (2010). Social psychophysiology and embodiment. In S. T.

Fiske, D. T. Gilbert, \& G. Lindzey (Eds.), Handbook of social psychology (p. 194-227).

John Wiley \& Sons, Inc. https://doi.org/10.1002/9780470561119.socpsy001006

Boyer, P. (2008). Religion explained. Random House.

Boyer, P. (2018). Minds make societies: How cognition explains the world humans create. Yale University Press.

Boyer, P., \& Liénard, P. (2006). Why ritualized behavior? Precaution systems and action parsing in developmental, pathological and cultural rituals. Behavioral and Brain Sciences, 29(6), 595-613. https://doi.org/10.1017/S0140525X06009332

Boyer, P., \& Petersen, M. B. (2018). Folk-economic beliefs: An evolutionary cognitive model. Behavioral and Brain Sciences, 41. https://doi.org/10.1017/S0140525X17001960

Brigham, N. L., Kelso, K. A., Jackson, M. A., \& Smith, R. H. (1997). The roles of invidious comparisons and deservingness in sympathy and schadenfreude. Basic and Applied Social Psychology, 19(3), 363-380. https://doi.org/10.1207/s15324834basp1903 6

Brown, M., Chua, K. J., \& Lukaszewski, A. W. (2021). Formidability and socioeconomic status uniquely predict militancy and political moral foundations. Personality and Individual Differences, 168, 110284. https://doi.org/10.1016/j.paid.2020.110284

Buss, D. M. (1991). Evolutionary personality psychology. Annual review of psychology, 42(1), 459-491. https://doi.org/10.1146/annurev.ps.42.020191.002331

Cacioppo, J. T., Gardner, W. L., \& Berntson, G. G. (1999). The affect system has parallel and integrative processing components: Form follows function. Journal of Personality and Social Psychology, 76(5), 839. https://psycnet.apa.org/doi/10.1037/0022$\underline{3514.76 .5 .839}$

Cheng, J. T., Tracy, J. L., Foulsham, T., Kingstone, A., \& Henrich, J. (2013). Two ways to the top: Evidence that dominance and prestige are distinct yet viable avenues to social rank and influence. Journal of Personality and Social Psychology, 104(1), 103-125. https://psycnet.apa.org/doi/10.1037/a0030398

Cheng, J. T., Tracy, J. L., \& Henrich, J. (2010). Pride, personality, and the evolutionary foundations of human social status. Evolution and Human Behavior, 31(5), 334-347. https://doi.org/10.1016/j.evolhumbehav.2010.02.004

Cohen, A. S., Chun, R., \& Sznycer, D. (2020). Do pride and shame track the evaluative psychology of audiences? Preregistered replications of Sznycer et al. (2016, 2017). Royal Society Open Science, 7: 191922. https://doi.org/10.1098/rsos.191922

Cohen, T. R., Panter, A. T., \& Turan, N. (2013). Predicting counterproductive work behavior from guilt proneness. Journal of Business Ethics, 114(1), 45-53. https://doi.org/10.1184/R1/6707429.v1

Cohen, T. R., Panter, A. T., Turan, N., Morse, L., \& Kim, Y. (2014). Moral character in the workplace. Journal of Personality and Social Psychology, 107(5), 943. https://doi.apa.org/doi/10.1037/a0037245

Cosmides, L., \& Tooby, J. (2006). Evolutionary psychology, moral heuristics, and the law. In G. Gigerenzer \& Christoph Engel (Eds.), Heuristics and the Law. MIT Press.

Cuddy, A. J. C., Fiske, S. T., \& Glick, P. (2008). Warmth and competence as universal dimensions of social perception: The stereotype content model and the BIAS map. 
Advances in Experimental Social Psychology, 40, 61-149. https://doi.org/10.1016/S00652601(07)00002-0

Curry, O. S., Mullins, D. A., \& Whitehouse, H. (2019). Is it good to cooperate? Testing the theory of Morality-as-Cooperation in 60 Societies. Current Anthropology, 60(1), 47-69. https://doi.org/10.1086/701478

Daly, M., \& Wilson, M. (1988). Homicide. Aldine de Gruyter.

Daly, M., \& Wilson, M. (1995). Discriminative parental solicitude and the relevance of evolutionary models to the analysis of motivational systems. In M. S. Gazzaniga (Ed.), The cognitive neurosciences (pp. 1269-1286). MIT Press.

Darwin, C. (1872). The expression of the emotions in man and animals. John Murray.

Davis, K. L., \& Panksepp, J. (2011). The brain's emotional foundations of human personality and the Affective Neuroscience Personality Scales. Neuroscience \& Biobehavioral Reviews, 35(9), 1946-1958. https://doi.org/10.1016/j.neubiorev.2011.04.004

de Hooge, I. E., Breugelmans, S. M., \& Zeelenberg, M. (2008). Not so ugly after all: When shame acts as a commitment device. Journal of Personality and Social Psychology, 95, 933-943. https://psycnet.apa.org/doi/10.1037/a0011991

Delton, A. W., \& Robertson, T. E. (2016). How the mind makes welfare tradeoffs: Evolution, computation, and emotion. Current Opinion in Psychology, 7, 12-16. https://doi.org/10.1016/j.copsyc.2015.06.006

DeScioli, P., \& Kurzban, R. (2013). A solution to the mysteries of morality. Psychological Bulletin, 139(2), 477-496. https://psycnet.apa.org/doi/10.1037/a0029065

Dickerson, S. S., Mycek, P. J., \& Zaldivar, F. (2008). Negative social evaluation, but not mere social presence, elicits cortisol responses to a laboratory stressor task. Health Psychology, 27, 116-121. https://psycnet.apa.org/doi/10.1037/0278-6133.27.1.116

Durkee, P. K., Lukaszewski, A. W., \& Buss, D. M. (2019). Pride and shame: Key components of a culturally universal status management system. Evolution and Human Behavior, 40(5), 740 470-478. https://doi.org/10.1016/j.evolhumbehav.2019.06.004

Ekman, P. (1992). An argument for basic emotions. Cognition and Emotion, 6, 169-200. https://doi.org/10.1080/02699939208411068

Elfenbein, H. A., \& Ambady, N. (2002). On the universality and cultural specificity of emotion recognition: A meta-analysis. Psychological Bulletin, 128(2), 203-235. https://doi.apa.org/doi/10.1037/0033-2909.128.2.203

Fehr, E., \& Gächter, S. (2000). Cooperation and punishment in public goods experiments. American Economic Review, 90(4), 980-994. https://doi.org/10.1257/aer.90.4.980

Felson, R. B. (1982). Impression management and the escalation of aggression and violence. Social Psychology Quarterly, 245-254. https://doi.org/10.2307/3033920

Fessler, D. M. T. (1999). In A. L. Hinton (Ed.), Toward an understanding of the universality of second order emotions. Cambridge University Press.

Foster, G. M. (1965). Peasant society and the image of limited good. American Anthropologist, 67(2), 293-315. https://doi.org/10.1525/aa.1965.67.2.02a00010

Friedman, D. (2005). Economics and evolutionary psychology. Advances in Austrian Economics, 7, 17-33. https://doi.org/10.1016/S1529-2134(04)07002-4

Friedman, O. (2010). Necessary for possession: How people reason about the acquisition of ownership. Personality and Social Psychology Bulletin, 36(9), 1161-1169. https://doi.org/10.1177\%2F0146167210378513 
Galati, D., Sini, B., Schmidt, S., \& Tinti, C. (2003). Spontaneous facial expressions in congenitally blind and sighted children aged 8-11. Journal of Visual Impairment and Blindness, 97(7), 418-428. https://doi.org/10.1177\%2F0145482X0309700704

Gershman, B. (2015). The economic origins of the evil eye belief. Journal of Economic Behavior \& Organization, 110, 119-144. https://doi.org/10.1016/j.jebo.2014.12.002

Gervais, M. M., \& Fessler, D. M. (2017). On the deep structure of social affect: Attitudes, emotions, sentiments, and the case of "contempt". Behavioral and Brain Sciences, 40. https://doi.org/10.1017/S0140525X16000352

Gilbert, P. (1997). The evolution of social attractiveness and its role in shame, humiliation, guilt and therapy. British Journal of Medical Psychology, 70, 113-147. https://doi.org/10.1111/j.2044-8341.1997.tb01893.x

Gilbert, P. (2000). The relationship of shame, social anxiety and depression: The role of the evaluation of social rank. Clinical Psychology \& Psychotherapy, 7, 174-189. https://doi.org/10.1002/1099-0879(200007)7:3\%3C174::AID-CPP236\%3E3.0.CO;2-U

Gordon, A. M., Impett, E. A., Kogan, A., Oveis, C., \& Keltner, D. (2012). To have and to hold: Gratitude promotes relationship maintenance in intimate bonds. Journal of Personality and Social Psychology, 103(2), 257. https://doi.apa.org/doi/10.1037/a0028723

Gramzow, R., \& Tangney, J. P. (1992). Proneness to shame and the narcissistic personality. Personality and Social Psychology Bulletin, 18(3), 369-376. https://psycnet.apa.org/doi/10.1177/0146167292183014

Hagen, E. H. (1999). The functions of postpartum depression. Evolution and Human Behavior, 20(5), 325-359. https://doi.org/10.1016/S1090-5138(99)00016-1

Hagen, E. H., \& Barrett, H. C. (2007). Perinatal sadness among Shuar women: Support for an evolutionary theory of psychic pain. Medical Anthropology Quarterly, 21(1), 22-40. https://doi.org/10.1525/maq.2007.21.1.22

Haidt, J. (2012). The righteous mind: Why good people are divided by politics and religion. Paragon.

Hamilton, W. D. (1964). The genetical evolution of social behaviour. II. Journal of theoretical biology, 7(1), 17-52. https://doi.org/10.1016/0022-5193(64)90039-6

Hare, T. A., Camerer, C. F., Knoepfle, D. T., O'Doherty, J. P., \& Rangel, A. (2010). Value computations in ventral medial prefrontal cortex during charitable decision making incorporate input from regions involved in social cognition. Journal of Neuroscience, 30(2), 583-590. https://doi.org/10.1523/JNEUROSCI.4089-09.2010

Hill, S.E., \& Buss, D.M. (2008). The evolutionary psychology of envy. In R. Smith (Ed.), The psychology of envy (pp. 60-70). Guilford.

Jackendoff, R. (2006). The peculiar logic of value. Journal of Cognition and Culture, 6, 375407. https://doi.org/10.1163/156853706778554922

Jones, O. D. (2001). Proprioception, non-law, and biolegal history. Florida Law Review, 53(5), 831-874.

Jones, O. D., \& Goldsmith, T. H. (2005). Law and behavioral biology. Columbia Law Review, 105(2), 405-502.

Jones, D. N., \& Paulhus, D. L. (2014). Introducing the short dark triad (SD3) a brief measure of dark personality traits. Assessment, 21(1), 28-41. https://doi.org/10.1177\%2F1073191113514105 
Kääriäinen, J. (2018). Seven criminal cases-Comparing Finnish Punishment policies and Finns' punishment preferences. Helsinki, Finland: University of Helsinki Institute of Criminology and Legal Policy, Research Report 27/2018.

Kanngiesser, P., Rossano, F., Frickel, R., Tomm, A., \& Tomasello, M. (2020). Children, but not great apes, respect ownership. Developmental Science, 23(1), e12842. https://doi.org/10.1111/desc. 12842

Kaplan, H., \& Hill, K. (1985). Food sharing among ache foragers: Tests of explanatory hypotheses. Current Anthropology, 26, 223-239. https://doi.org/10.1086/203251

Keller, M. C., \& Nesse, R. M. (2006). The evolutionary significance of depressive symptoms: Different adverse situations Lead to different depressive symptom patterns. Journal of Personality and Social Psychology, 91, 316-330. https://doi.apa.org/doi/10.1037/0022$\underline{3514.91 .2 .316}$

Keltner, D., \& Haidt, J. (1999). Social functions of emotions at four levels of analysis. Cognition \& Emotion, 13(5), 505-521. https://doi.org/10.1080/026999399379168

Keltner, D., Young, R. C., \& Buswell, B. N. (1997). Appeasement in human emotion, social practice, and personality. Aggressive Behavior, 23, 359-374. https://psycnet.apa.org/doi/10.1002/(SICI)1098-2337(1997)23:5\%3C359::AID$\mathrm{AB} 5 \% 3 \mathrm{E} 3.0 . \mathrm{CO} ; 2-\mathrm{D}$

Ketelaar, T., \& Au, W. T. (2003). The effects of feelings of guilt on the behaviour of uncooperative individuals in repeated social bargaining games: An affect-as-information interpretation of the role of emotion in social interaction. Cognition and Emotion, 17, 429-453. https://doi.org/10.1080/02699930143000662

Klein, J. T., Deaner, R. O., \& Platt, M. L. (2008). Neural correlates of social target value in macaque parietal cortex. Current Biology, 18(6), 419-424. https://doi.org/10.1016/j.cub.2008.02.047

Krizan, Z., \& Johar, O. (2012). Envy divides the two faces of narcissism. Journal of personality, 80(5), 1415-1451. https://doi.org/10.1111/j.1467-6494.2012.00767.x

Landers, M., Sznycer, D., \& Al-Shawaf, L. (this volume). Shame.

Lang, M., Purzycki, B. G., Apicella, C. L., Atkinson, Q. D., Bolyanatz, A., Cohen, E., Handley, C., Kundtová Klocová, E., Lesorogol, C., \& Mathew, S. (2019). Moralizing gods, impartiality and religious parochialism across 15 societies. Proceedings of the Royal Society B, 286(1898), 20190202. https://doi.org/10.1098/rspb.2019.0202

Leach, C. W., \& Cidam, A. (2015). When is shame linked to constructive approach orientation? A meta-analysis. Journal of Personality and Social Psychology, 109(6), 983-1002. https://psycnet.apa.org/doi/10.1037/pspa0000037

Leary, M. R., Tambor, E. S., Terdal, S. K., \& Downs, D. L. (1995). Self-esteem as an interpersonal monitor: The sociometer hypothesis. Journal of Personality and Social Psychology, 68, 518-530. https://psycnet.apa.org/doi/10.1037/0022-3514.68.3.518

Leith, K. P., \& Baumeister, R. F. (1998). Empathy, shame, guilt, and narratives of interpersonal conflicts: Guilt-prone people are better at perspective taking. Journal of Personality, 66(1), 1-37. https://psycnet.apa.org/doi/10.1111/1467-6494.00001

Levy, D. J., \& Glimcher, P. W. (2012). The root of all value: A neural common currency for choice. Current Opinion in Neurobiology, 22(6), 1027-1038. https://doi.org/10.1016/j.conb.2012.06.001

Lewis, M., Alessandri, S. M., \& Sullivan, M. W. (1992). Differences in shame and pride as a 
function of children's gender and task difficulty. Child Development, 63, 630-638. https://doi.org/10.2307/1131351

Lieberman, D., \& Linke, L. (2007). The effect of social category on third party punishment. Evolutionary Psychology, 5(2), 289-305. https://doi.org/10.1177\%2F147470490700500203

Lieberman, D., \& Patrick, C. (2018). Objection: Disgust, morality, and the law. Oxford University Press.

Lieberman, D., Tooby, J., \& Cosmides, L. (2007). The architecture of human kin detection. Nature, 445(7129), 727. https://doi.org/10.1038/nature05510

Lim, J. (2012). Welfare Tradeoff ratios and emotions: psychological foundations of human reciprocity. Doctoral dissertation. Santa Barbara: University of California.

Lin, C. A., \& Bates, T. C. (2020). Who supports redistribution? Replicating and refining effects of compassion, malicious envy, and self-interest. Evolution and Human Behavior. https://doi.org/10.1016/j.evolhumbehav.2020.08.010

Lukaszewski, A. W. (2020). Evolutionary perspectives on the mechanistic underpinnings of personality. In J. Rauthmann (Ed.), The handbook of personality dynamics and processes. Elsevier Press.

Lukaszewski, A. W., Lewis, D. M., Durkee, P. K., Sell, A. N., Sznycer, D., \& Buss, D. M. (2020). An adaptationist framework for personality science. European Journal of Personality, 34(6), 1151-1174. https://doi.org/10.1002/per.2292

Lukaszewski, A. W., Simmons, Z. L., Anderson, C., \& Roney, J. R. (2015). The role of physical formidability in human social status allocation. Journal of Personality and Social Psychology, 110, 385-406. https://doi.apa.org/doi/10.1037/pspi0000042

Manson, J. H., Wrangham, R. W., Boone, J. L., Chapais, B., Dunbar, R. I. M., Ember, C. R., Irons, W., Marchant, L. F., McGrew, W. C., \& Nishida, T. (1991). Intergroup aggression in chimpanzees and humans. Current Anthropology, 32(4), 369-390. https://doi.org/10.1007/s12110-012-9132-1

Mesquita, B. (2001). Emotions in collectivist and individualist contexts. Journal of Personality and Social Psychology, 80(1), 68-74. https://doi.apa.org/doi/10.1037/00223514.80.1.68

Michalak, J., Troje, N. F., Fischer, J., Vollmar, P., Heidenreich, T., \& Schulte, D. (2009). Embodiment of sadness and depression-Gait patterns associated with dysphoric mood. Psychosomatic Medicine, 71(5), 580-587. 10.1097/PSY.0b013e3181a2515c

Mischel, W., \& Shoda, Y. (1995). A cognitive-affective system theory of personality: reconceptualizing situations, dispositions, dynamics, and invariance in personality structure. Psychological review, 102(2), 246. https://doi.apa.org/doi/10.1037/0033295X.102.2.246

Montag, C., \& Panksepp, J. (2017). Primary emotional systems and personality: an evolutionary perspective. Frontiers in psychology, 8, 464. https://doi.org/10.3389/fpsyg.2017.00464

Nelson, N. L., \& Russell, J. A. (2014). Dynamic facial expressions allow differentiation of displays intended to convey positive and hubristic pride. Emotion, 14(5), 857. https://psycnet.apa.org/doi/10.1037/a0036789

Nesse, R. M. (1990). Evolutionary explanations of emotions. Human Nature, 1, 261-289. https://doi.org/10.1007/BF02733986

Noë, R., \& Hammerstein, P. (1994). Biological markets: supply and demand determine the effect 
of partner choice in cooperation, mutualism and mating. Behavioral ecology and sociobiology, 35(1), 1-11. https://psycnet.apa.org/doi/10.1007/BF00167053

Nowak, M. A., \& Sigmund, K. (1998). Evolution of indirect reciprocity by image scoring. Nature, 393(6685), 573-577. https://doi.org/10.1038/31225

Ohtsubo, Y., \& Yagi, A. (2015). Relationship value promotes costly apology-making:

Testing the valuable relationships hypothesis from the perpetrator's perspective.

Evolution and Human Behavior, 36(3), 232-239.

https://doi.org/10.1016/j.evolhumbehav.2014.11.008

Patrick, C. J. (2016). The Long-Term Promise of Evolutionary Psychology for the Law. Arizona State Law Journal, 48, 995-1012.

Petersen, M. B., Sell, A., Tooby, J., \& Cosmides, L. (2012). To punish or repair? Evolutionary psychology and lay intuitions about modern criminal justice. Evolution and Human Behavior, 33(6), 682-695. https://doi.org/10.1016/j.evolhumbehav.2012.05.003

Petersen, M. B., Sznycer, D., Cosmides, L., \& Tooby, J. (2012). Who deserves help? Evolutionary psychology, social emotions, and public opinion about welfare. Political Psychology, 33(3), 395-418. https://doi.org/10.1111/j.1467-9221.2012.00883.x

Petersen, M. B., Sznycer, D., Sell, A., Cosmides, L., \& Tooby, J. (2013). The ancestral logic of politics: Upper-body strength regulates men's assertion of self-interest over economic redistribution. Psychological Science, 24(7), 1098-1103. https://doi.org/10.1177\%2F0956797612466415

Pietraszewski, D., Curry, O. S., Petersen, M. B., Cosmides, L., \& Tooby, J. (2015). Constituents of political cognition: Race, party politics, and the alliance detection system. Cognition, 140, 24-39. https://doi.org/10.1016/j.cognition.2015.03.007

Riskind, J. H., \& Gotay, C. C. (1982). Physical posture: Could it have regulatory or feedback effects on motivation and emotion? Motivation and Emotion, 6(3), 273-298. https://doi.org/10.1007/BF00992249

Robertson, T. E., Sznycer, D., Delton, A. W., Tooby, J., \& Cosmides, L. (2018). The true trigger of shame: Social devaluation is sufficient, wrongdoing is unnecessary. Evolution and Human Behavior, 39, 566-573. https://doi.org/10.1016/j.evolhumbehav.2018.05.010

Robinson, P. H., Goodwin, G. P., \& Reisig, M. D. (2010). The disutility of injustice. New York University Law Review, 85, 1940-2033.

Robinson, P H, \& Kurzban, R. (2007). Concordance and conflict in intuitions of justice. Minnesota Law Review, 91, 1829-1907.

Robinson, P. H., Kurzban, R., \& Jones, O. D. (2007). The origins of shared intuitions of justice. Vanderbilt Law Review, 60(6), 1633-1688.

Rubin, P. H. (2003). Folk economics. Southern Economic Journal, 157-171. https://doi.org/10.2307/1061637

Russell, J. A. (1980). A circumplex model of affect. Journal of Personality and Social Psychology, 39(6), 1161. https://psycnet.apa.org/doi/10.1037/h0077714

Salmon, C. A., \& Shackelford, T. K. (2007). Family relationships: An evolutionary perspective. Oxford University Press.

Saucier, G., \& Goldberg, L. R. (1996). Evidence for the Big Five in analyses of familiar English personality adjectives. European journal of Personality, 10(1), 61-77. https://psycnet.apa.org/doi/10.1002/(SICI)1099-0984(199603)10:1\%3C61::AIDPER246\%3E3.0.CO;2-D 
Scherer, K. R., \& Wallbott, H. G. (1994). Evidence for universality and cultural variation of differential emotion response patterning. Journal of Personality and Social Psychology, 66, 310-328. https://doi.apa.org/doi/10.1037/0022-3514.66.2.310

Schniter, E., Sheremeta, R. M., \& Sznycer, D. (2013). Building and rebuilding trust with promises and apologies. Journal of Economic Behavior and Organization, 94, 242-256. https://doi.org/10.1016/j.jebo.2012.09.011

Schniter, E., Shields, T. W., \& Sznycer, D. (2020). Trust in humans and robots: Economically similar but emotionally different. Journal of Economic Psychology, 78, 102253. https://doi.org/10.1016/j.joep.2020.102253

Schoeck, H. (1969). Envy: A theory of social behavior. Harcourt, Brace, and World.

Schwarz, N. (2000). Emotion, cognition, and decision making. Cognition \& Emotion, 14(4), 433-440. https://doi.org/10.1080/026999300402745

Sell, A. N. (2011). The recalibrational theory and violent anger. Aggression and Violent Behavior, 16(5), 381-389. https://doi.org/10.1016/j.avb.2011.04.013

Sell, A., Cosmides, L., \& Tooby, J. (2014). The human anger face evolved to enhance cues of strength. Evolution and Human Behavior, 35(5), 425-429. https://doi.org/10.1016/j.evolhumbehav.2014.05.008

Sell, A. \& Sznycer, D. (this volume) The recalibrational theory: Anger as a bargaining emotion.

Sell, A., Sznycer, D., Cosmides, L., Tooby, J., Krauss, A., Nisu, S., Ceapa, C., \& Petersen, M. B. (2017). Physically strong men are more militant: A test across four countries. Evolution and Human Behavior, 38(3), 334-340. https://doi.org/10.1016/j.evolhumbehav.2016.11.002

Sell, A., Tooby, J., \& Cosmides, L. (2009). Formidability and the logic of human anger. Proceedings of the National Academy of Sciences, 106(35), 15073-15078. https://doi.org/10.1073/pnas.0904312106

Siegel, E. H., Sands, M. K., Van den Noortgate, W., Condon, P., Chang, Y., Dy, J., ... Barrett, L. F. (2018). Emotion fingerprints or emotion populations? A meta-analytic investigation of autonomic features of emotion categories. Psychological Bulletin, 144(4), 343-393. https://doi.apa.org/doi/10.1037/bul0000128

Smith, A., Pedersen, E. J., Forster, D. E., McCullough, M. E., \& Lieberman, D. (2017). Cooperation: The roles of interpersonal value and gratitude. Evolution and Human Behavior, 38(6), 695-703. http://dx.doi.org/10.1016/j.evolhumbehav.2017.08.003

Smith, R. H., Webster, J. M., \& Eyre, H. L. (2002). The role of public exposure in moral and nonmoral shame and guilt. Journal of Personality and Social Psychology, 83, 138-159. https://psycnet.apa.org/doi/10.1037/0022-3514.83.1.138

Smith, R. H., \& Kim, S. H. (2007). Comprehending envy. Psychological Bulletin, 133(1), $46-64$. https://psycnet.apa.org/doi/10.1037/0033-2909.133.1.46

Stylianou, S. (2003). Measuring crime seriousness perceptions: What have we learned and what else do we want to know. Journal of Criminal Justice, 31(1), 37-56. https://doi.org/10.1016/S0047-2352(02)00198-8

Sznycer, D. (2010). Cognitive adaptations for calibrating welfare tradeoff motivations, with special reference to the emotion of shame (Doctoral dissertation). Santa Barbara: University of California.

Sznycer, D. (2019). Forms and functions of the self-conscious emotions. Trends in Cognitive Sciences, 23(2), 143-157. https://doi.org/10.1016/j.tics.2018.11.007 
Sznycer, D., Al-Shawaf, L., Bereby-Meyer, Y., Curry, O. S., De Smet, D., Ermer, E., ... Seal, M. F. L. (2017). Cross-cultural regularities in the cognitive architecture of pride. Proceedings of the National Academy of Sciences, 114(8), 1874-1879. https://doi.org/10.1073/pnas.1614389114

Sznycer, D., Barlev, M., Lopez Seal, M. F., Tooby, J., \& Cosmides, L. (in prep.). The psychology of zero-sum games.

Sznycer, D. \& Cohen, A. S. (forthcoming-a). How pride works.

Sznycer, D. \& Cohen, A. S. (forthcoming-b). Are emotions natural kinds after all? Rethinking the issue of response coherence.

Sznycer, D., Cosmides, L., \& Tooby, J. (2017). Adaptationism carves emotions at their functional joints. Psychological Inquiry, 28(1), 56-62. https://psycnet.apa.org/doi/10.1080/1047840X.2017.1256132

Sznycer, D., Delton, A. W., Robertson, T. E., Cosmides, L., \& Tooby, J. (2019). The ecological rationality of helping others: Potential helpers integrate cues of recipients' need and willingness to sacrifice. Evolution and Human Behavior, 40(1), 34-45. https://doi.org/10.1016/j.evolhumbehav.2018.07.005

Sznycer, D., \& Patrick, C. (2020). The origins of criminal law. Nature Human Behaviour, 4(5), 506-516. https://doi.org/10.1038/s41562-020-0827-8

Sznycer, D., De Smet, D., Billingsley, J., \& Lieberman, D. (2016). Coresidence duration and cues of maternal investment regulate sibling altruism across cultures. Journal of Personality and Social Psychology, 111(2), 159-177. https://doi.apa.org/doi/10.1037/pspi0000057

Sznycer, D., Ermer, E., \& Tooby, J. (2018). Why do people think that others should earn this or that? Behavioral and Brain Sciences, 41, e189. https://doi.org/10.1017/S0140525X18000559

Sznycer, D. \& Lukaszewski, A. W. (2019). The emotion-valuation constellation: Multiple emotions are governed by a common grammar of social valuation. Evolution and Human Behavior, 40(4), 395-404. https://doi.org/10.1016/j.evolhumbehav.2019.05.002

Sznycer, D., Schniter, E., Tooby, J., \& Cosmides, L. (2015). Regulatory adaptations for delivering information: The case of confession. Evolution and Human Behavior, 36, 4451. https://doi.org/10.1016/j.evolhumbehav.2014.08.008

Sznycer, D., Seal, M. F. L., Sell, A., Lim, J., Porat, R., Shalvi, S., Halperin, E., Cosmides, L., \& Tooby, J. (2017). Support for redistribution is shaped by compassion, envy, and selfinterest, but not a taste for fairness. Proceedings of the National Academy of Sciences, 114(31), 8420-8425. https://doi.org/10.1073/pnas.1703801114

Sznycer, D., Sell, A., \& Lieberman, D. (forthcoming). Forms and functions of the social emotions.

Sznycer, D., Takemura, K., Delton, A. W., Sato, K., Robertson, T., Cosmides, L., \& Tooby, J. (2012). Cross-cultural differences and similarities in proneness to shame: An adaptationist and ecological approach. Evolutionary Psychology, 10, 352-370. https://doi.org/10.1177\%2F147470491201000213

Sznycer, D., Tooby, J., Cosmides, L., Porat, R., Shalvi, S., \& Halperin, E. (2016). Shame closely tracks the threat of devaluation by others, even across cultures. Proceedings of the National Academy of Sciences, 113(10), 2625-2630. https://doi.org/10.1073/pnas.1514699113 
Sznycer, D., Xygalatas, D., Agey, E., Alami, S., An, X.-F., Ananyeva, K. I., ... Tooby, J. (2018). Cross-cultural invariances in the architecture of shame. Proceedings of the National Academy of Sciences, 115(39), 9702-9707. https://doi.org/10.1073/pnas.1805016115

Sznycer, D., Xygalatas, D., Alami, S., An, X.-F., Ananyeva, K. I., Fukushima, S., \& Tooby, J. (2018). Invariances in the architecture of pride across small-scale societies. Proceedings of the National Academy of Sciences, 115(33), 8322-8327.

https://doi.org/10.1073/pnas.1808418115

Tangney, J. P. (1991). Moral affect: The good, the bad, and the ugly. Journal of Personality and Social Psychology, 61, 598-607. https://doi.apa.org/doi/10.1037/0022-3514.61.4.598

Tesser, A., Gatewood, R., \& Driver, M. (1968). Some determinants of gratitude. Journal of Personality and Social Psychology, 9(3), 233. https://psycnet.apa.org/doi/10.1037/h0025905

Tooby, J. (1985). The emergence of evolutionary psychology. In D. Pines (Ed.), Emerging syntheses in science (pp. 67-76). Santa Fe Institute.

Tooby, J., \& Cosmides, L. (1988). The evolution of war and its cognitive foundations. Institute for Evolutionary Studies Technical Report, 88(1), 1-15.

Tooby, J., \& Cosmides, L. (1990). The past explains the present: Emotional adaptations and the structure of ancestral environments. Ethology and sociobiology, 11(4-5), 375-424. https://doi.org/10.1016/0162-3095(90)90017-Z

Tooby, J., \& Cosmides, L. (1992). The psychological foundations of culture. In J. Barkow, L. Cosmides, \& J. Tooby (Eds.), The adapted mind: Evolutionary psychology and the generation of culture (pp. 19-136). Oxford University Press.

Tooby, J., \& Cosmides, L. (1996). Friendship and the Banker's Paradox: Other pathways to the evolution of adaptations for altruism. In W. G. Runciman, J. Maynard Smith, \& R. I. M. Dunbar (Eds.), Evolution of Social Behaviour Patterns in Primates and Man. Proceedings of the British Academy (Vol. 88, pp. 119-143).

Tooby, J., \& Cosmides, L. (2008). In M. Lewis, J. M. Haviland-Jones, \& L. F. Barrett (Eds.), The evolutionary psychology of the emotions and their relationship to internal regulatory variables. Guilford.

Tooby, J., \& Cosmides, L. (2010). Groups in mind: The coalitional roots of war and morality. In H. Høgh-Olesen, (Ed.), Human morality and sociality: Evolutionary and comparative perspectives (pp. 191-234). Palgrave MacMillan.

Tooby, J., Cosmides, L., \& Price, M. E. (2006). Cognitive adaptations for n-person exchange: The evolutionary roots of organizational behavior. Managerial and Decision Economics, 27(2-3), 103-129. https://doi.org/10.1002/mde.1287

Tooby, J., Cosmides, L., Sell, A., Lieberman, D., \& Sznycer, D. (2008). Internal regulatory variables and the design of human motivation: A computational and evolutionary approach. Handbook of approach and avoidance motivation. Vol. 15. Handbook of approach and avoidance motivation (pp. 251-271).

Tracy, J. L., Shariff, A. F., \& Cheng, J. T. (2010). A naturalist's view of pride. Emotion Review, 2(2), 163-177. https://doi.org/10.1177\%2F1754073909354627

Tracy, J. L., \& Matsumoto, D. (2008). The spontaneous display of pride and shame: Evidence for biologically innate nonverbal displays. Proceedings of the National Academy of Sciences, 105, 11655-11660. https://doi.org/10.1073/pnas.0802686105

Tracy, J. L., \& Robins, R. W. (2008). The nonverbal expression of pride: Evidence for cross- 
cultural recognition. Journal of Personality and Social Psychology, 94, 516-530.

https://doi.apa.org/doi/10.1037/0022-3514.94.3.516

Trivers, R. L. (1971). The evolution of reciprocal altruism. The Quarterly review of biology, 46(1), 35-57. https://doi.org/10.1086/406755

Tsang, J.-A. (2006a). Gratitude and prosocial behaviour: An experimental test of gratitude. Cognition \& Emotion, 20(1), 138-148. https://psycnet.apa.org/doi/10.1080/02699930500172341

Tsang, J.-A. (2006b). The effects of helper intention on gratitude and indebtedness. Motivation and Emotion, 30(3), 198-204. https://psycnet.apa.org/doi/10.1007/s11031-006-9031-z

Van Der Schalk, J., Bruder, M., \& Manstead, A. (2012). Regulating emotion in the context of interpersonal decisions: The role of anticipated pride and regret. Frontiers in Psychology, 3, 1-9. https://doi.org/10.3389/fpsyg.2012.00513

van Dijk, W. W., Ouwerkerk, J. W., Smith, R. H., \& Cikara, M. (2015). The role of selfevaluation and envy in schadenfreude. European Review of Social Psychology, 26(1), 247-282. https://psycnet.apa.org/doi/10.1080/10463283.2015.1111600

von Fürer-Haimendorf C. (1967) Moral and Merit: A study of values and social controls in South Asian societies. Weidenfeld and Nicolson.

Weisfeld, G. (1999). In J. M. G. van Der Dennen, D. Smillie, \& D. R. Wilson (Eds.), Darwinian analysis of the emotion of pride/shame. Praeger Publishers.

Weisfeld, G. E., \& Dillon, L. M. (2012). Applying the dominance hierarchy model to pride and shame, and related behaviors. Journal of Evolutionary Psychology, 10(1), 15-41. https://psycnet.apa.org/doi/10.1556/JEP.10.2012.1.2

Welling, H. (2003). An evolutionary function of the depressive reaction: The cognitive map hypothesis. New Ideas in Psychology, 21(2), 147-156. https://psycnet.apa.org/doi/10.1016/S0732-118X(03)00017-5

Wicker, F. W., Payne, G. C., \& Morgan, R. D. (1983). Participant descriptions of guilt and shame. Motivation and Emotion, 7, 25-39. https://doi.org/10.1007/BF00992963

Williams, L. A., \& DeSteno, D. (2008). Pride and perseverance: The motivational role of pride. Journal of Personality and Social Psychology, 94(6), 1007-1017. https://psycnet.apa.org/doi/10.1037/0022-3514.94.6.1007

Williams, K. E., Votruba, A. M., Neuberg, S. L., \& Saks, M. J. (2019). Capital and punishment: Resource scarcity increases endorsement of the death penalty. Evolution and Human Behavior, 40(1), 65-73. https://doi.org/10.1016/j.evolhumbehav.2018.08.002

Xygalatas, D., Mitkidis, P., Fischer, R., Reddish, P., Skewes, J., Geertz, A. W., Roepstorff, A., \& Bulbulia, J. (2013). Extreme rituals promote prosociality. Psychological Science, 24(8), 1602-1605. https://doi.org/10.1177\%2F0956797612472910 